\title{
María Victoria Utrera Torremocha: Estructura y teoría del verso libre. Madrid: Consejo Superior de Investigaciones Científicas, 2010.
}

El libro Estructura y teoría del verso libre, de la profesora María Victoria Utrera Torremocha, viene a llenar el vacío existente en los estudios sobre el versolibrismo desde el año 1985, cuando Isabel Paraíso publicó su monografía El verso libre hispánico. Orígenes y corrientes. La doctora Utrera, profesora titular de Teoría de la Literatura y Literatura Comparada en la Facultad de Filología de la Universidad de Sevilla, ya se ocupó del verso libre en algunos artículos y, fundamentalmente, en el trabajo Historia y teoría del verso libre, de 2001, donde realizó una primera aproximación al tema. Del mismo modo, abordó el poema en prosa, género que presenta muchas concomitancias con el verso libre, en Teoría del poema en prosa, de 1999.

El libro que se publica este año recoge las ideas sobre el verso libre de diversos críticos, como Pedro Henríquez Ureña, Tomás Navarro Tomás, José Domínguez Caparrós, Isabel Paraíso, Francisco López Estrada, Carlos Bousoño, Amado Alonso, Oldrich Bělič o Esteban Torre, entre otros. Asimismo, no deja al margen la opinión de los propios poetas que lo cultivaron en alguna de sus variantes, entre ellos Thomas Stearns Eliot, Luis Cernuda, Jorge Luis Borges, Dámaso Alonso, Juan Ramón Jiménez o Ricardo Jaimes Freyre.

La abundante información ofrecida al respecto se estructura en cinco capítulos. Se trata de un tema complejo, dado el terreno fronterizo, tanto en lo referente a los géneros literarios como a los cauces expresivos, en el que se mueve esta modalidad lírica. Precisamente de esta cuestión -de las fronteras del verso libre-se ocupa el primer capítulo del volumen, donde la autora se refiere a la versificación semilibre, el versículo, el verso de cláusulas $-\mathrm{y}$, en general, el verso de base acentual-, las adaptaciones del hexámetro latino o la métrica fluctuante propia de la literatura medieval castellana, es decir, a todo aquello que dificulta la delimitación del verso libre, ocasionando discrepancias entre poetas y críticos. Asimismo, traza sus antecedentes en diversas literaturas: en la francesa -en la que, dejando al margen el versículo whitmaniano, cabría situar el origen del verso libre moderno-, pero también en las literaturas alemana, inglesa, rusa, italiana y, por supuesto, española. 
En cuanto a los dos siguientes capítulos, abordan el desarrollo histórico del verso libre, tanto en lo referente a la plasmación práctica como a los planteamientos teóricos, en los siglos XIX y XX respectivamente. No en vano, en palabras de la autora, "más que entender el versolibrismo como el desarrollo y la continuación de formas anteriores, es necesario vincularlo a la ruptura con la norma isosilábica imperante a fines del siglo XIX y principios del XX", por lo que carece de sentido hablar de verso libre en los siglos anteriores. Concretamente, el segundo capítulo se centra en Walt Whitman; los poetas simbolistas franceses, entre los que la autora destaca a Gustave Kahn -no sólo por su obra poética, sino también por su reflexión sobre el versolibrismo- y a Jules Laforgue; y los modernistas, como Ricardo Jaimes Freyre, Rubén Darío o Leopoldo Lugones. Por su parte, el capítulo siguiente traza el desarrollo histórico posterior a partir de las vanguardias. En esta época han merecido la atención de la autora las poéticas de Thomas Stearns Eliot, William Carlos Williams, Ezra Pound, Jorge Luis Borges, Gerardo Diego, Vicente Huidobro, César Vallejo, Juan Ramón Jiménez, Luis Cernuda, Federico García Lorca, Rafael Alberti, Pedro Salinas, Dámaso Alonso, Vicente Aleixandre, Luis Antonio de Villena, Juan Luis Panero, Ana Rosetti, Blanca Andreu o Luis García Montero, entre otros. Además, María Victoria Utrera se sirve del estudio de estos autores para ejemplificar los diferentes tipos de verso libre $\mathrm{y}$, por tanto, continuar trazando su análisis teórico. Así, por ejemplo, determina que "muchos de los textos que se consideran escritos en verso libre responden a menudo a los esquemas regulares subvertidos en mayor o menor medida", por lo que no se podrían denominar estrictamente poemas versolibristas. En concreto, resulta habitual que se trate de adaptaciones de la silva clásica, que combinan distintos metros impares. De hecho, existe en el siglo Xx un claro retorno a la métrica tradicional, que se encuentra ligada, en todo caso, a la poesía versolibrista, ya que, en palabras de la autora, ésta "se asienta en la tensión y continua confrontación con el verso tradicional".

Una cuestión fundamental en las tentativas de definición del verso libre es el ritmo personal. La mayoría de los estudiosos, a los que se hace aquí referencia, ha destacado que el ritmo de pensamiento, manifestado en figuras literarias como la enumeración, el paralelismo $u$ otras basadas en la repetición, resulta clave en la definición del verso libre, puesto que puede ejercer la función iterativa del metro. A pesar de ello, María Victoria Utrera señala que "no puede ser considerado con propiedad como un sistema de 
versificación, ni es algo exclusivo ni intrínseco a la poesía libre", si bien dota al verso -o a la prosa- de "poeticidad". La inclusión del verso libre en la categoría de verso o de prosa viene motivada, como se expone en el último capítulo, por varios factores, entre los que ha de considerarse siempre la base rítmica regular. No se puede desdeñar, por una parte, la importancia de las convenciones, esto es, de la tradición; ni, por otra, la cuestión tipográfica, que influye en el horizonte de expectativas del lector, si bien la condición de verso será, en última instancia, confirmada o no tras la percepción del ritmo en la lectura.

En conclusión, María Victoria Utrera Torremocha ofrece al lector interesado en la teoría de la lírica y, en concreto, en el verso libre una monografía que plantea con extremo rigor teórico la opinión de poetas y críticos de distintas épocas, en una visión de conjunto necesaria para entender una modalidad tan difícil de definir como es el versolibrismo.

EnRiQue Martín DíEZ 